\title{
US lacks back-up for flu vaccine shortfall
}

Helen Pearson, New York

Public-health officials in the United States were left scrambling for alternative sources of influenza vaccine last week, after the surprise announcement that half the country's supply for this winter had been shelved.

The problem came to a head on 5 October, when British regulators suspended the production of flu vaccine at the Californiabased Chiron Corporation's facility in Liverpool, UK, because of concerns over bacterial contamination. The suspension jeopardizes around half of the US supply.

In Britain, where about $20 \%$ of this year's requirement was to come from the Liverpool plant, public-health officials have been able to arrange alternative supplies. But the US government says that it cannot do the same.

In an emergency hearing of the government reform committee of the House of Representatives on 8 October, vaccine manufacturers, congressmen and public-health officials blamed each other for the lack of a contingency plan. "We need a surge capacity," said Julie Gerberding, director of the Centers for Disease Control and Prevention in Atlanta, Georgia, "and we simply do not have it."

The episode highlights the vulnerability of the current influenza vaccine manufacturing process, says infectious-disease specialist Donald Burke at Johns Hopkins Bloomberg School of Public Health in Baltimore. "It's a frustration to all of us that the system is as fragile as it is."

Flu vaccines are mass-produced by growing the virus in fertilized hen's eggs. About one egg is needed per dose, so vast numbers are ordered from specially bred hens as much as

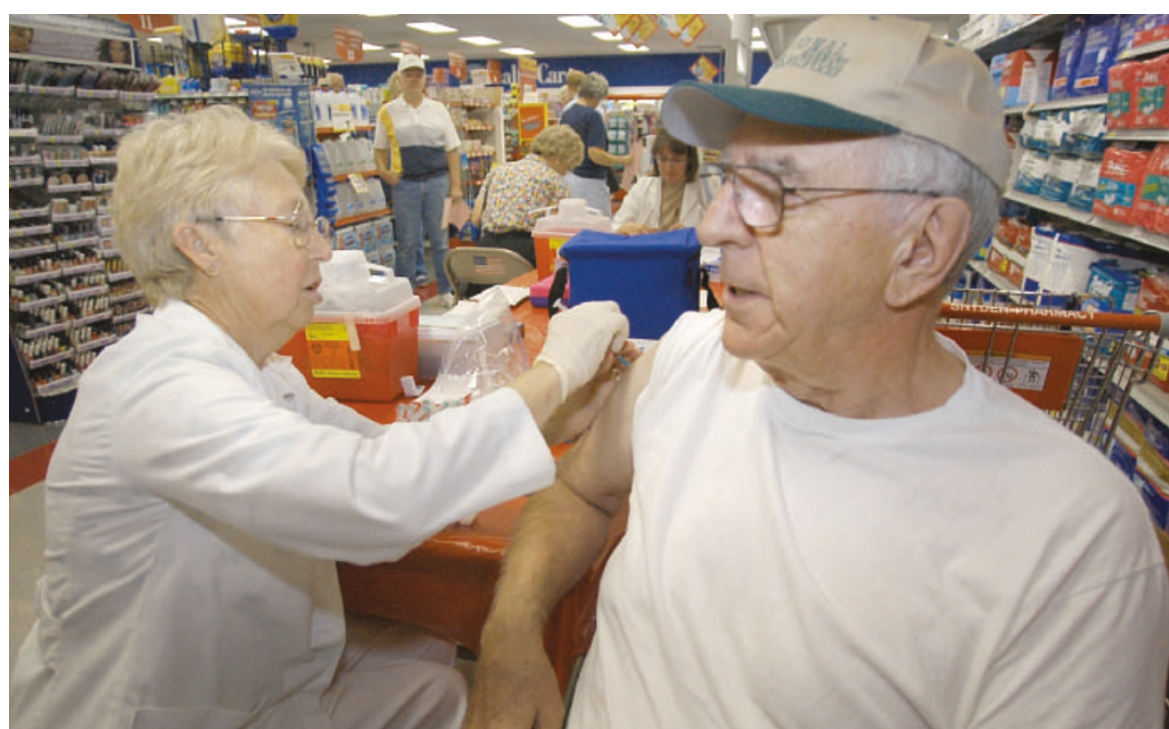

Making sure: Americans are getting their flu jabs early this year as a vaccine shortage looms.

three years before production begins.

Each egg is injected with a tiny dose of the flu virus selected for the current year's jab. The virus grows for several days in the fluid surrounding the embryo before the eggs are sliced open, the liquid sucked out, and the virus extracted from the fluid and inactivated. The entire process, including safety tests on the vaccine, takes five to six months.

Egg-based production is tried, tested and reliable - but cannot manufacture vaccine at short notice. One way to bypass eggs is to produce the virus in mammalian cell cultures, which can be set up more quickly. The virus multiplies in the cells and is then filtered out of the reactor.
Brussels-based Solvay Pharmaceuticals has built a production plant for making flu vaccine in cell culture, and hopes that the first batches will be licensed and available by 2006 . But the process has not taken off widely because most companies are reluctant to invest in expensive new equipment - and vaccines produced this way will still have lengthy safety testing and regulatory approval.

Even if production time can be squeezed, critics say that flu vaccine supply is vulnerable because only three companies are licensed to produce it for the US market. Many pharmaceutical companies are dissuaded from making vaccines because they return relatively little profit compared with drugs.

\section{Californians up in arms over water assessment}

\section{Emma Marris, Washington}

California legislators are demanding an inquiry into allegations that a local office of the National Oceanic and Atmospheric Administration (NOAA) reversed the findings of its own biologists in assessing a water-management plan for the state.

An early version of the plan, which Nature was shown, states that a strategy for managing the estuary around San Francisco Bay is "likely to jeopardize the continued existence" of two subspecies of fish, the Sacramento River winter-run chinook salmon and the Central Valley steelhead.

But a later version of the plan - dated September 2004 - comes to the opposite conclusion, stating that it "is not likely to result in jeopardy to the continued existence" of these fish.

Environmentalists claim that the first version of the document was prepared by NOAA biologists in the Sacramento area office and that staff at NOAA Fisheries Southwest Regional Office in Long Beach, California, then rewrote it, with input from the US Bureau of Reclamation, a branch of the interior department, which drew up the water-management plan in the first place. Their claims were first reported in the Sacramento Bee on 2 October.

Bill Jennings, head of the watchdog group Deltakeeper, calls the revision "an outrageous sacrifice of sound science on the altar of expediency, that will lead to the further degradation of fisheries throughout the Central Valley".

But Jim Lecky, a marine biologist and NOAA official charged with preparing the final report, says that the original version failed to take account of recent adjustments to the water-management plan. "It's much ado about nothing," he says. "There were some key errors made by the staff. It's not a matter of changing the science."

Last week, California state senator Michael Machado called for an independent review of the process. And in Washington, Congressman George Miller (Democrat, California) and 18 other members asked the inspector generals at the interior department and the commerce department - of which NOAA is part - to investigate.

Lecky says that a final version of the assessment will be published in a few weeks.

For more news and analysis go to news@nature.com www.nature.com/news 